\title{
Effectivity of Vetiveria zizanioides and Cyperus papyrus in Reducing Iron (Fe) Concentration in Wastewater Processed in a Constructed Wetland System
}

\author{
Arma Yulisa and Devi N. Choesin
}

\begin{abstract}
Iron (Fe) and iron-containing compounds are used in various industries and thus Fe production in the world has reached more than 500 million tons per year. The use of $\mathrm{Fe}$ in various industrial processes and its high presence in the environment can potentially pollute water bodies and be toxic to aquatic biota. The application of constructed wetland systems provides an alternative approach to treat this problem. This study was conducted to examine the effectiveness of a surface flow constructed wetland system, planted with Vetiveria zizanioides and Cyperus papyrus, in reducing $\mathrm{Fe}$ concentration in simulated wastewater. Experimental systems were exposed to artificial wastewater containing $\mathrm{FeSO}_{4} \cdot 7 \mathrm{H}_{2} \mathrm{O}$, equivalent to $60 \mathrm{ppm} \mathrm{Fe}$ concentration. Each experimental run was conducted for 18 days by comparing five different systems: system-A as control contained only wastewater; system-B contained wastewater and substrate; system-C contained wastewater, substrate and planted with $V$. zizanioides; system-D contained wastewater, substrate and planted with $C$. papyrus; while system-E contained wastewater, substrate, and planted with both $V$. zizanioides and $C$. papyrus. Measurements were conducted on Fe concentration and physical-chemical parameters of wastewater, substrate and air. Results indicate that system- $\mathrm{C}$ was most effective in decreasing $\mathrm{Fe}$ concentration to reach the maximum allowable concentration (MAC) $(20 \mathrm{ppm})$ when compared to the other systems. On the sixth day of treatment, Fe concentration in system-C reached $16.2 \mathrm{ppm}$, i.e., a reduction percentage of $70 \%$. On the same day, $\mathrm{Fe}$ concentration in system-E measured $16.6 \mathrm{ppm}$ (69\% reduction). System-D and system-B reached the permitted level on the ninth day with reduction percentage of $62 \%$ and $61 \%$ respectively. Meanwhile, as control, system-A was the slowest in decreasing $\mathrm{Fe}$ concentration; on the twelfth day, Fe concentration reached 18.1 ppm, i.e., a reduction of $65 \%$. Statistical analysis showed that there was a significant difference among systems in $\mathrm{Fe}$ concentration reduction in wastewater on the sixth to fifteenth day of observation ( $\mathrm{p}<0.05$ ). Results of this study indicated that the addition of $V$. zizanioides and $C$. papyrus can improve system effectiveness in reducing Fe concentration.
\end{abstract}

Keywords-Constructed wetland, Fe concentration, Vetiveria zizanioides, Cyperus papyrus

\section{INTRODUCTION}

Metallic iron ( $\mathrm{Fe})$ and its compounds are used in various industries, including pharmaceutical, chemical, fertilizer and pesticides, textile, automotive, and construction industries. To meet these needs, the production of $\mathrm{Fe}$ in the world has reached more than 500 million tons per year. In addition, Fe compounds can also be formed as a result of various activities such as mining [1].

\section{Manuscript received 18 January 2016.}

Authors are affiliated with the Biology program, School of Life Sciences and Technology, Institut Teknologi Bandung, Jalan Ganesha 10, Bandung 40132, Indonesia
The use of $\mathrm{Fe}$ in a variety of industries results in a high probability of this element contaminating aquatic ecosystems. Water bodies that have been contaminated with Fe may have a $\mathrm{pH}$ range between 2.0 to 4.5 which is toxic to aquatic life. These low $\mathrm{pH}$ values will disrupt the growth and reproduction of aquatic biota [2]. Studies have also cited that low $\mathrm{pH}$ conditions can alter gill membranes resulting in fish death due to hypoxia. Particulate Fe sediment that covers the surface of river and lake sediment can also disrupt the availability of clean gravel that serves as spawning sites and reduce benthic macroinvertebrates numbers as fish food. Therefore, $\mathrm{Fe}$ compounds that pollute water bodies will damage aquatic habitats biologically, physically and chemically [3].

The application of constructed wetland systems is one approach to addressing the problem of metal contamination, including Fe. Constructed wetland systems have been developed for wastewater treatment. In the working principle of constructed wetlands, pollutants in the system will encounter sedimentation, precipitation, adsorption to soil particles, assimilation by plant tissues, and transformation by microbes. In other words, pollutants contained in wetland systems will be treated through a series of physical, chemical and biological processes [4]-[8].

Wetland plants are important components of wetland ecosystems because of their role in the process of sewage treatment [8]. Amongst various species, Vetiveria zizanioides and Cyperus papyrus are often used for phytoremediation purposes because these plants are able to respond to alteration of long term water levels and have good adaptability in extreme environmental conditions [9]-[11]. The following study was conducted to examine the effectivity of a free water surface wetland planted with $V$. zizanioides and $C$. papyrus in reducing Fe concentration in wastewater.

\section{Methodology}

Experimental constructed wetland systems with free water surface were made from glass aquariums measuring $60 \mathrm{~cm}$ in length, $30 \mathrm{~cm}$ in width and $30 \mathrm{~cm}$ in height. Five different systems were compared in this study. System-A as control only contained simulated wastewater containing Fe (coded: $\mathrm{w}+\mathrm{Fe})$; system-B contained wastewater and substrate $(\mathrm{w}+\mathrm{Fe}+\mathrm{S})$; system-C contained wastewater, substrate and planted $V$. zizanioides $(\mathrm{w}+\mathrm{Fe}+\mathrm{S}+\mathrm{V})$; system-D contained wastewater, substrate and $C$. papyrus $(\mathrm{w}+\mathrm{Fe}+\mathrm{S}+\mathrm{Cy})$; finally, system-E contained wastewater, substrate, and planted with both $V$. zizanioides and $C$. papyrus $(\mathrm{w}+\mathrm{Fe}+\mathrm{S}+\mathrm{V}+\mathrm{Cy})$. Experiments were replicated three times. Simulated wastewater treated into each system was made by dissolving $10.5 \mathrm{~g} \mathrm{FeSO}_{4} .7 \mathrm{H}_{2} \mathrm{O}$ in $35 \mathrm{~L}$ of distilled water in order to obtain Fe concentration of $60 \mathrm{ppm}$. Wastewater was flowed 
into the systems through an inlet point, then wastewater flowing out of the outlet point was collected in a container before being recirculated into the inlet point (Fig. 1). Retention time for each circulation was 15 minutes, as determined by equation (1) [12].

$$
t=\frac{\text { System Volume }(L)}{\text { Water Discharge }\left(\frac{L}{\text { minute }}\right)}
$$

Each experimental run was conducted for 18 days. Measurements of Fe concentrations in wastewater, substrate and roots of plants, as well as physicochemical conditions of wastewater and substrate were carried out every three days.

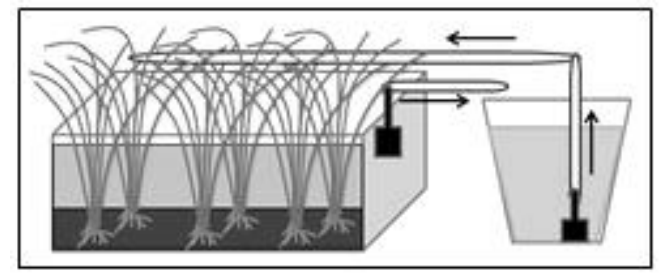

Fig. 1. Constructed wetland system used in this study.

Physical and chemical parameters of wastewater measured include $\mathrm{pH}$, TDS (total dissolved solids), TSS (total suspended solids) and Fe concentration. These parameters were measured using $\mathrm{pH}$ meter for $\mathrm{pH}$, TDS meter for TDS, TSS meter for TSS, and atomic absorption spectrophotometer (AAS) for $\mathrm{Fe}$ concentration. Physical and chemical parameters of substrate measured include $\mathrm{pH}$ using $\mathrm{pH}$ tester and Fe concentration by AAS analysis.

Wet ashing method was used for the preparation of wastewater, substrate and plant root samples before analysis for Fe concentration. Fifty $\mathrm{mL}$ each of wastewater samples, 1 $\mathrm{g}$ of substrate samples and $3 \mathrm{~g}$ of plant root samples that have been dried at $80^{\circ} \mathrm{C}$ were dissolved in $50 \mathrm{~mL} \mathrm{HNO}_{3}$. In the next step, samples were kept in the hood for 12 hours and then heated at $125^{\circ} \mathrm{C}$ for 45 minutes. After cooling at room temperature, samples were added with $1 \mathrm{~mL}$ of $\mathrm{H}_{2} \mathrm{O}_{2} 30 \%$ and re-heated at $125^{\circ} \mathrm{C}$ temperature for 45 minutes. Addition of $\mathrm{H}_{2} \mathrm{O}_{2} 30 \%$ and heating at temperature of $125^{\circ} \mathrm{C}$ were continued until samples appeared clear [13]. Sufficient $\mathrm{HNO}_{3}$ was added to the samples in order to measure $\mathrm{Fe}$ concentration using AAS at a wavelength $(\lambda)$ of $248.3 \mathrm{~nm}$ [14].

\section{RESULTS AND DISCUSSION}

Measurement results show a decrease of Fe concentration in wastewater processed by the systems tested (Fig. 2). From the five treatments, system- $\mathrm{C}$ and system-E reduced $\mathrm{Fe}$ concentrations faster than the other treatments.

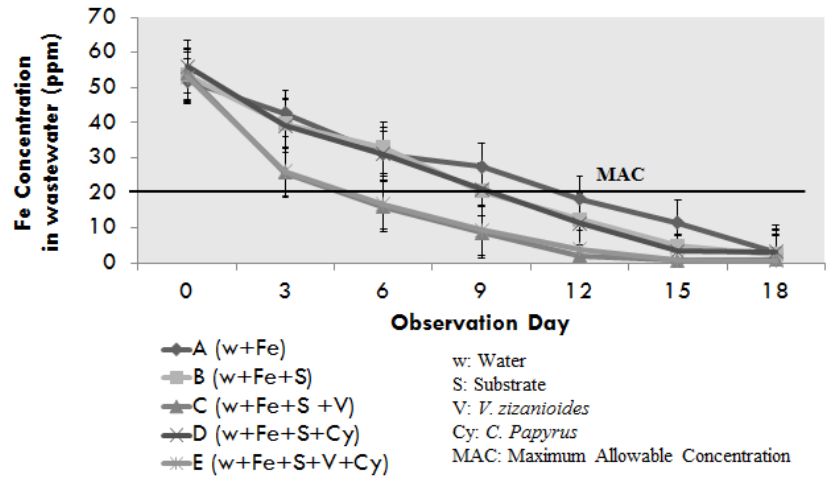

Fig. 2. Fe concentration in wastewater.

Measurement results also indicate increasing $\mathrm{Fe}$ concentrations in substrate of the four systems containing substrate (Fig. 3). Fe concentrations in system-C and system-E showed a high increase on the $3^{\text {rd }}$ day until the $12^{\text {th }}$ day of observation. These results may be related to the presence of $V$. zizanioides in system-C and system-E. The morphology of $V$. zizanioides is very appropriate to select as a constructed wetland plant because it has stiff stems and forms dense hedges to restrict pollutant movement. This condition greatly enhances the process of pollutant sedimentation [15].

On the $12^{\text {th }}$ until $18^{\text {th }}$ day of observation, Fe concentrations in substrate of systems planted with vegetation (system-C, system-D and system-E) showed reduction. This reduction may be related to the accumulation of Fe from substrate in plant root areas. In system-B which was not planted with vegetation, sedimentation of Fe compounds merely occurred due to substrate, causing $\mathrm{Fe}$ concentration in the system to increase up to the $18^{\text {th }}$ day of observation.

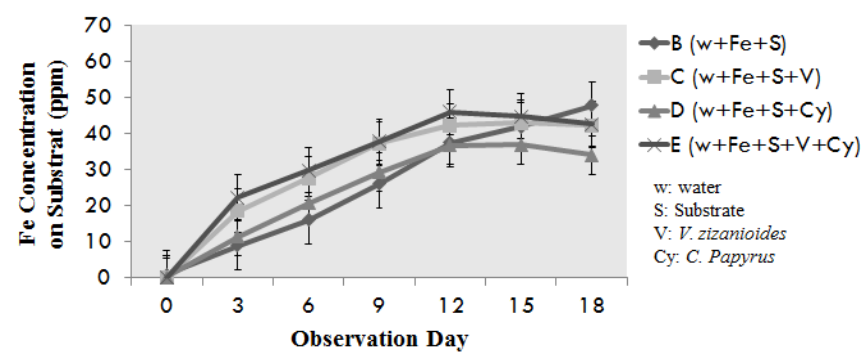

Fig. 3. Fe concentration in substrate.

From the graph of percent decrease in wastewater $\mathrm{Fe}$ concentration (Fig. 4), it can be seen that Fe concentrations decreased by $90 \%$ within 18 days in all systems.

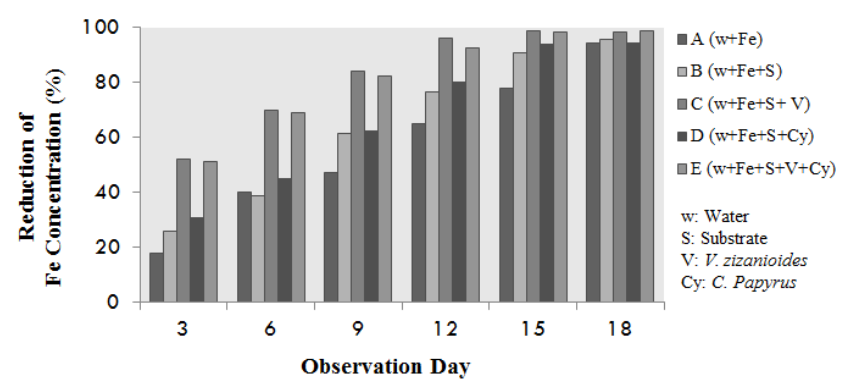

Fig. 4. Percentage of Fe concentration reduction in wastewater.

However, each system reached the Fe maximum allowable concentration (MAC) of $20 \mathrm{ppm}$ at different times (Table 1). System-C reached MAC most effectively and in the shortest amount of time, while system-A as control needed the longest amount of time. Statistical analysis showed that there was a significant difference among systems in reducing 
concentrations of $\mathrm{Fe}$ in wastewater on the $6^{\text {th }}$ day of observation until the the $15^{\text {th }}$ day of observation $(\mathrm{p}<0.05)$.

TABLE I: ACHIEVEMENT OF MAXIMUM ALLOWABLE CONCENTRATION (20 PPM)

\begin{tabular}{|l|c|c|c|}
\hline \multicolumn{1}{|c|}{ System } & $\begin{array}{c}\text { Observa- } \\
\text { tion day }\end{array}$ & $\begin{array}{c}\text { Fe Concen- } \\
\text { tration }(\mathrm{ppm})\end{array}$ & $\begin{array}{c}\text { Percen- } \\
\text { tage }(\%)\end{array}$ \\
\hline $\mathrm{A}(\mathrm{w}+\mathrm{Fe})$ & $12^{\text {th }}$ & $18.1 \pm 0.7$ & 65 \\
\hline $\mathrm{B}(\mathrm{w}+\mathrm{Fe}+\mathrm{S})$ & $9^{\text {th }}$ & $20.6 \pm 2.1$ & 61 \\
\hline $\mathrm{C}(\mathrm{w}+\mathrm{Fe}+\mathrm{S}+\mathrm{V})$ & $6^{\text {th }}$ & $16.2 \pm 5.5$ & 70 \\
\hline $\mathrm{D}(\mathrm{w}+\mathrm{Fe}+\mathrm{S}+\mathrm{Cy})$ & $9^{\text {th }}$ & $21.1 \pm 3.7$ & 62 \\
\hline $\mathrm{E}(\mathrm{w}+\mathrm{Fe}+\mathrm{S}+\mathrm{V}+\mathrm{Cy})$ & $6^{\text {th }}$ & $16.6 \pm 4.3$ & 69 \\
\hline
\end{tabular}

The presence of vegetation in a constructed wetland system does not only optimize the process of sedimentation but also absorbs heavy metal [16]. Measurement results (Fig. 5) indicate increasing Fe concentrations around plant root areas after treated. However, this escalation was not statistically different among systems $(\alpha=0.05 ; p=0.961)$.

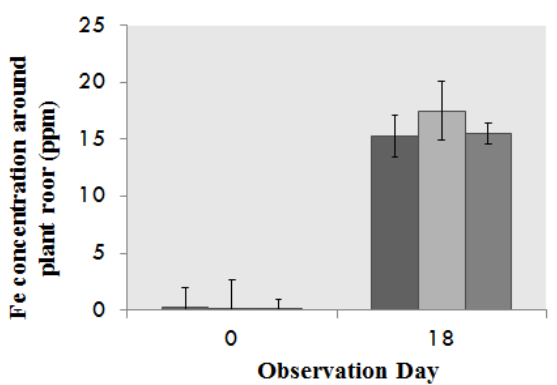

$$
\begin{aligned}
& \square \mathrm{C}(\mathrm{w}+\mathrm{Fe}+\mathrm{S}+\mathrm{V}) \\
& \square \mathrm{D}(\mathrm{w}+\mathrm{Fe}+\mathrm{S}+\mathrm{Cy}) \\
& \square(\mathrm{w}+\mathrm{Fe}+\mathrm{S}+\mathrm{V}+\mathrm{Cy}) \\
& \text { w: Water } \\
& \text { S: Substrate } \\
& \text { V: } \text { V. zizanioides } \\
& \text { Cy: C. Papyrus }
\end{aligned}
$$

Fig. 5. Fe concentration around plant root areas.

Wetland plant roots are the first organ that plays a role in heavy metal absorption. The first stage is phytoaccumulation, which is the accumulation of pollutants from growth media to the root. The next is rhizofiltration which is an adsorption process or deposition of pollutants to cling around the roots. The next stage is phytostabilization in which pollutants that cannot be absorbed into the stem become attached to the roots. Attachment of these substances is very strong and stable, thus it will not be carried away by the flow of water in the media. The next stage is known as rhizodegradation which is the decomposition of pollutants around roots with the help of microbes. The last stage is phytodegradation or phytotransformation [17].

The process of wet ashing of plant roots in this study followed Plank's method [13]. In wet ashing, roots were only cleaned from soil particles. Therefore, results of $\mathrm{Fe}$ concentration measurements in root samples could not be assumed to be entirely Fe absorbed into the roots. However, measurements are assumed to be accumulated around the root area and will be absorbed by the roots. From the literature it is known that heavy metals accumulate around roots before they can be absorbed by the roots [17].

Fe is a plant micronutrient that is needed in small amount. This element is a constituent of cytochrome and non-heme iron protein involved in photosynthesis, $\mathrm{N}_{2}$ fixation and respiration. Fe present in the substrate is absorbed by roots through the root apex or directly through the root surface. After Fe is absorbed by the roots, it will oxidize to ferric form and translocate to the leaves [18].

Water $\mathrm{pH}$ value is an important parameter of water that determines the solubility and availability of nutrients, including metals such as Fe. Solubility refers to the amount of substance that dissolves in water. $\mathrm{FeSO}_{4} .7 \mathrm{H}_{2} \mathrm{O}$ solubility in water will rise at low $\mathrm{pH}$. Fe is dissolved in water in the form of ferrous ions which will be oxidized to become particulate and precipitate [19].

Measurement results (Fig. 6) show that wastewater $\mathrm{pH}$ at the beginning of the treatment was very low. In this condition, the solubility of ferrous ions from $\mathrm{FeSO}_{4} \cdot 7 \mathrm{H}_{2} \mathrm{O}$ compound was higher compared to the end of experimental treatment.

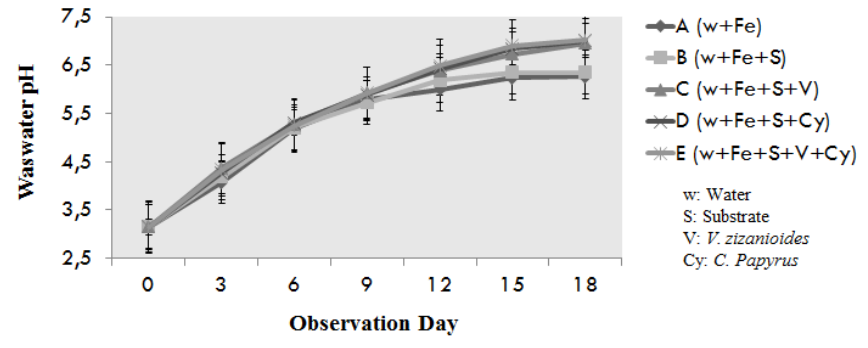

Fig. 6. Wastewater $\mathrm{pH}$

Wastewater $\mathrm{pH}$ value continued to increase until the $18^{\text {th }}$ day of observation. The increase in wastewater $\mathrm{pH}$ is associated with the solubility reduction of iron compounds in wastewater due to sedimentation; thus measurements indicate a decrease in substrate $\mathrm{pH}$ (Table 2).

TABLE 2: SUBSTRATE PH (WITHIN A COLUMN, DIFFERENT LETTERS INDICATE SIGNIFICANT DIFFERENCE AT P < 0.05)

\begin{tabular}{|l|c|c|}
\hline \multicolumn{1}{|c|}{ System } & Before treatment & After treatment \\
\hline $\mathrm{B}(\mathrm{w}+\mathrm{Fe}+\mathrm{S})$ & $(6.4 \pm 0.1)^{\mathrm{a}}$ & $(3.9 \pm 0.1)^{\mathrm{b}}$ \\
\hline $\mathrm{C}(\mathrm{w}+\mathrm{Fe}+\mathrm{S}+\mathrm{V})$ & $(6.4 \pm 0.1)^{\mathrm{a}}$ & $(3.9 \pm 0.1)^{\mathrm{b}}$ \\
\hline $\mathrm{D}(\mathrm{w}+\mathrm{Fe}+\mathrm{S}+\mathrm{Cy})$ & $(6.4 \pm 0.1)^{\mathrm{a}}$ & $(4.0 \pm 0.1)^{\mathrm{bc}}$ \\
\hline $\mathrm{E}(\mathrm{w}+\mathrm{Fe}+\mathrm{S}+\mathrm{V}+\mathrm{Cy})$ & $(6.4 \pm 0.1)^{\mathrm{a}}$ & $(4.2 \pm 0.1)^{\mathrm{c}}$ \\
\hline
\end{tabular}

Results of TSS and TDS measurements in wastewater showed that the decrease of TSS and TDS concentrations was followed by decreasing $\mathrm{Fe}$ concentrations in wastewater. From the literature, it is known that suspended and dissolved material in water include carbonate, bicarbonate, chloride, sulfate, phosphate, nitrate, calcium, magnesium, sodium, and other ions including ferrous ions, dissolved metals and pathogens [20]. Although TSS and TDS measurements cannot indicate exactly the concentration or changes of material in the water, TSS and TDS concentrations are parameters that must also be considered in monitoring water quality, including wastewater [20].

Therefore, the mechanisms that occurred decreasing $\mathrm{Fe}$ concentration in this study involve three main processes, i.e., chemical, physical and biological. Chemical processes occurred when ferrous ion from $\mathrm{FeSO}_{4} \cdot 7 \mathrm{H}_{2} \mathrm{O}$ dissolved in water underwent oxidation to form ferric ions. Ferric ion is a particulate form with low solubility in water, resulting in physical processes that precipitate particulate Fe to substrate [8][19]. Meanwhile, biological processes involved the plant's role in the system. In addition to retarding the water flow, wetland plants also absorb pollutants present in the system [16].

\section{CONCLUSION}

The five constructed wetland systems that were varied based on the presence of substrate and plants were effective in reducing Fe concentrations to reach the maximum allowable level of $20 \mathrm{ppm}$ after 18 days of treatment. However, the 
addition of $V$. zizanioides and $C$. papyrus could improve system effectivity by decreasing Fe concentration in a shorter time period.

\section{REFERENCES}

[1] World Steel and Iron Association. 2014. World Steel and Iron in Figures. Belgium: Print Speed Paper.

[2] Fromm PO. 1980. A review of some physiological and toxicological responses of freshwater fish to acid stress. Environmental Biology of Fishes. 5 (1): 79-93. http://dx.doi.org/10.1007/BF00000954

[3] Jennings SR, Neuman DR, Blicker PS. 2008. Acid Mine Drainage and Effect on Fish Health and Ecology: A Review. Montana: Reclamation Research Group Publication.

[4] Chong HLH, Ahmad MN, Lim PE. 2003. Constructed wetlands: treatment of heavy metals utilising agricultural wastes as media. Proceedings of Environment. 7.

[5] Khatiwada NR, Polprasert C. 1999. Kinetics of faecal coliform removal in constructed wetlands. Water Sci. Technol. 40 (3): 109. http://dx.doi.org/10.1016/S0273-1223(99)00446-1

[6] Ahmad MN, Artsanti P, Lim PE, Suryani S, Abdul KHPS. 2003. The efficiency of charcoal as filter media in non-vegetation constructed wetland subsurface-flow system (SF) for ammonia, chemical oxygen demand and iron treatment of landfill leachate. Indonesian J. Chem. 3 (3): $135-140$.

[7] Tan FWN, Ibrahim MS, Lim PE. 2007. Constructed wetlands for reactive dye and nitrogen removal. Southeast Asian Water Environment. 2: 287-294.

[8] Brix H. 1994. Functions of macrophytes in constructed wetlands. Wat. Sci. Tech. 29: 71-78.

[9] Powell R. 1990. Leaf and Branch - Tree and tall shrubs of Perth. Australia: Department of Conservation and Land Management.

[10] Kantawanichkul S, Pilaila S, Tanapiyawanich W. 1999. Wastewater treatment by tropical plants in vertical-flow constructed wetlands. Water Science \& Technology. 40 (3): 173 - 178. http://dx.doi.org/10.1016/S0273-1223(99)00462-X

[11] Gupta P, Roy S, Mahindrakar, AB. 2012. Treatment of water using water hyacinth, water lettuce and vetiver grass-A review. Resources and Environment. 2 (5): 202 - 215. http://dx.doi.org/10.5923/j.re.20120205.04

[12] Chang N, Xuan Z, Wanielista MP. 2011. A tracer study for assessing the interaction between hydraulic retention time and transport processes in a wetland system for nutrient removal. Bioprocess Biosyst Eng.

[13] Plank CO. 1992. Plant Analysis Reference Procedures for The Southern Region of The United States. Georgia: The University of Georgia.

[14] Ahmed MJ, Roy UK. 2009. A simple spectrophotometric method for the determination of iron (II) aqueous solution. Turk. J. Chem. 33: 709 $-726$.

[15] Truong PN. 2000. The Vetiver Grass System: Potential Applications for Soil and Water Conservation in Northern California. Woodland, Yolo Country, California.

[16] Herrs M. 2006. Masters Thesis-Constructed wetlands under different geographic conditions: Evaluation of the suitability and criteria for the choice of plants including productive species. Hamburg University of Applied Sciences, Germany Faculty of Life Sciences pp 165.

[17] Suresh, B. and G.A. Ravishankar. 2004. Phytoremediation - A novel and promising approach for environmental clean-up. Crit. Rev. Biotechnol. 24 (2-3): 97-124. http://dx.doi.org/10.1080/07388550490493627

[18] Taiz L, Zeiger E. 2003. Plant Physiology. Sunderland: Sinaeur Associates.

[19] Metzger M. 2005. The relationship between iron and $\mathrm{pH}$. Cleveland: National Testing Laboratory, Ltd.

[20] Rusdianasari, Arita S, Ibrahim E, Ngudiantoro. 2013. Evaluation of environmental effect of coal stockpile in Muara Telang, Banyuasin, Indonesia. Journal of Physics: Conference Series. 423. 